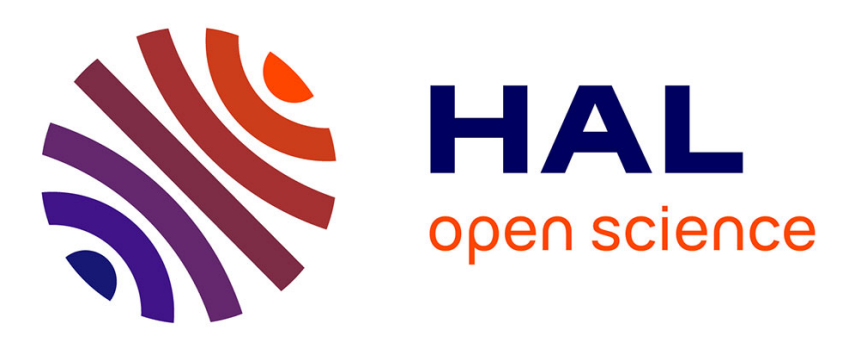

\title{
Changes in management modify agro-diversity in sainfoin swards in the Eastern Pyrenees
}

\author{
Sebastià, Palero, Bello
}

\section{To cite this version:}

Sebastià, Palero, Bello. Changes in management modify agro-diversity in sainfoin swards in the Eastern Pyrenees. Agronomy for Sustainable Development, 2011, 31 (3), pp.533-540. 10.1007/s13593011-0008-2 . hal-00930556

\section{HAL Id: hal-00930556 https://hal.science/hal-00930556}

Submitted on 1 Jan 2011

HAL is a multi-disciplinary open access archive for the deposit and dissemination of scientific research documents, whether they are published or not. The documents may come from teaching and research institutions in France or abroad, or from public or private research centers.
L'archive ouverte pluridisciplinaire HAL, est destinée au dépôt et à la diffusion de documents scientifiques de niveau recherche, publiés ou non, émanant des établissements d'enseignement et de recherche français ou étrangers, des laboratoires publics ou privés. 


\title{
Changes in management modify agro-diversity in sainfoin swards in the Eastern Pyrenees
}

\author{
Maria-Teresa Sebastià • Noemí Palero • \\ Francesco de Bello
}

Accepted: 29 July 2010 / Published online: 18 March 2011

(C) INRA and Springer Science+Business Media B.V. 2011

\begin{abstract}
Management affects ecosystem structure in many ways. Structural changes in ecosystems, including shifts in vegetation composition and species diversity, will affect the goods and services provided at ecosystem and regional scales. This is relevant for agricultural production and agrobiodiversity preservation in the context of management changes currently occurring in many regions. We sampled 39 sainfoin swards in the Eastern Pyrenees to assess changes in vegetation structure with sward management and evaluated how those changes might sustain agrodiversity regionally. Three sward managements coexist in the region: (a) mown plus sheep-grazed, (b) mown plus cattle-grazed and (c) only mown. Plant species composition and richness, and various biomass variables were estimated at peak biomass on swards with the three managements and different ages. We used a synchronic approach to study
\end{abstract}

M.-T. Sebastià $(\bowtie) \cdot$ N. Palero $\cdot$ F. de Bello

Forest Technology Centre of Catalonia (CTFC),

Pujada del Seminari s/n,

25280 Solsona, Spain

e-mail: teresa.sebastia@ctfc.es

URL: http://ecofun.ctfc.cat

\section{M.-T. Sebastià}

Agricultural Engineering School, University of Lleida, 25198 Lleida, Spain

Present Address:

N. Palero

Centre de la Propietat Forestal (CPF) Torreferrusa,

Ctra de Sabadell a Santa Perpètua,

$\mathrm{Km} \mathrm{4.5,}$

08130 Santa Perpètua de Mogoda, Spain

Present Address:

F. de Bello

Institute of Botany, Czech Academy of Sciences,

CZ-379 82 Třeboň, Czech Republic time effects, in which swards of different ages are sampled simultaneously, in a space by time substitution. Multivariate analysis and similarity indices revealed strong shifts in vegetation composition with management, enhanced with sward age, when the suppressive effect of sown on unsown plants relaxed. Generally, plant species richness increased with time. Old mown swards showed the highest number of species per plot $\left(34\right.$ in $4 \mathrm{~m}^{2}$ ). Cattle-grazed swards showed the highest within- and between-treatment vegetation dissimilarity with time. Biomass variables responded mainly to time effects, but total aboveground biomass decreased with unsown species and increased with species richness depending on management. Thus, the diversity of managements modified the expected outcome in local and regional agro-diversity and sward structure. Our results are novel because they demonstrate strong effects of grazing by different animals on local and regional agro-diversity and herbage composition in those ephemeral legume-based forage systems. Farmers and managers should take into account those shifts in order to achieve agricultural goals, including agro-diversity conservation and sustainable forage production at ecosystem and regional scales.

Keywords Agroecosystem - Community assembly . Grazing $\cdot$ Mowing $\cdot$ Onobrychis viciifolia $\cdot$ Plant species diversity

\section{Introduction}

Agroecosystems are important to humans because they provide fundamental goods and services whose quantity and quality can be modified through management (Kirwan et al. 2007). Management can affect ecosystem structure in many different ways, including shifts in vegetation compo- 
sition and plant species diversity (Sebastià et al. 2008; Semelová et al. 2008). Structural changes with management have been related to shifts in ecosystem function (Clergue et al. 2005; Quétier et al. 2007), which is relevant in order to guarantee the sustainability of agroecosystems. Changes in structure and function occurring in the ecosystems within a given region will affect the goods and services provided at the regional scale (Nelson et al. 2009). This is relevant in the context of changes in management currently occurring in many regions.

Grazing was found to decrease plant species richness and forage quality compared with mowing in semi-natural meadows (Hansson and Fogelfors 2000; Fischer and Wipf 2002). Similarly, changes in grazing intensity were found to affect plant diversity and functional type composition in pastures (Cingolani et al. 2005; Sebastià et al. 2008) and productivity and forage quality in cultivated swards (Pavlů et al. 2006). Other studies relate the variation in vegetation composition to the particular livestock species (del Pozo et al. 1998; Rook et al. 2004; Bakker et al. 2006). Vegetation and grazing herbivores influence each other reciprocally in a dynamic relationship (Marriott and Carrère 1998). Selective livestock as goat were found to consume the dominant shrub species at proportions below those found at ground cover (Mellado et al. 2004). Sheep grazing has been shown to increase the dominance of unpalatable species such as Nardus stricta by negative selection (Grant et al. 1996; Sebastià et al. 2008) following complex patterns with soil fertility (Pakeman 2004). Relatively unselective livestock as cattle were found to consume a proportionally greater quantity of $N$. stricta than was present in $N$. strictadominated pastures (Common et al. 1998).

Work in grasslands in the northeast of the Iberian Peninsula has shown how management modifies vegetation structure at the ecosystem level and how the coexistence of various management regimes increases landscape and regional biodiversity over and above that determined by abiotic factors (de Bello et al. 2009). For instance, cattlegrazed subalpine grasslands showed fundamental differences from sheep-grazed ones in terms of plant species composition and diversity (Sebastià et al. 2008). However, those systems are perennial (Sebastià 2004) and the effect of a given grazer type can be experienced continuously for a long time, often by the same plants, because perennial grassland species can have extended longevity. In legumebased forage swards and other leys, on the contrary, the system is by definition ephemeral, normally lasting 34 years before it is reseeded and a new cycle starts. Sometimes, the sown crop is different from the former forage product, and rotation is not uncommon. Thus, it is unclear to which extent the effect of management in general and grazer type in particular can affect those ephemeral systems and how the coexistence of different managements within a region might promote agro-diversity and maintain sustainability throughout time.

Legume forage swards of sainfoin (Onobrychis viciifolia Scop.), alone or sometimes in mixtures with dactyl (Dactylis glomerata L.), are very common in midmountain areas in the Eastern Pyrenees and other calcareous temperate regions in the world (Delgado et al. 2005). Sainfoin presents many advantages in terms of high forage quality and good adaptability. However, it has limited resprouting capacity (Chassagne and Chambon 1993). This might cause a fast decrease in forage quantity and quality through an increase of open sites where unsown species can establish and thrive. It also increases the overall biodiversity, with additional environmental and aesthetic benefits (Sanderson et al. 2004). In addition, shifts in physiological and morphological traits (Thein et al. 2008) could determine sainfoin behaviour under different managements.

In order to assess changes in plant species composition and aboveground biomass with sward management and evaluate how those changes might sustain agrodiversity at the regional scale, we carried out a survey on sainfoin (O. viciifolia Scop.) swards of different age after sowing in the Eastern Pyrenees. Our questions were: (a) To which extent does sward management determine changes in vegetation composition and structure? (b) Are those changes linked to differences in sward dynamics after establishment or to initial differences associated to management that are amplified over time? (c) In that case, how would the coexistence of different sward managements within a region might contribute to the sustainability of agro-diversity? Differences in vegetation depending on sward management can be a consequence of filtering by current management of the plant species pool arriving through plant dispersal (Zobel et al. 2006) or be related to past management, for instance through the soil seed bank (Matejkova et al. 2003). In the first case, differences in vegetation will be apparent some time after sward establishment, whilst in the second case, differences will be more or less conspicuous since establishment. In order to asses the effect of sward age on vegetation, we used a synchronic approach of succession, in which swards of different ages are sampled simultaneously in order to reconstruct time effects, in a space by time substitution (Pickett 1989).

\section{Materials and methods}

\subsection{Location and sward sampling}

A survey on sainfoin (O. viciifolia Scop.) swards of different ages after sowing was carried out in the Eastern Pyrenees (between $42^{\circ} 01^{\prime}-42^{\circ} 09^{\prime} \mathrm{N}$ latitude and $1^{\circ} 22^{\prime}-$ 
$1^{\circ} 33^{\prime} \mathrm{E}$ longitude, Alt Urgell and Solsonès counties, north central Catalonia). Sampling was performed in mountain areas from 600 to 1,300 ma.s.l. with sub-Mediterranean climate, on limestone (soil pH between 7 and 8). Three sward management techniques are common in the area: (a) mown once a year and sheep-grazed, (b) mown once a year and cattle-grazed, and (c) only mown twice a year. The main harvest is the spring harvest. The second harvest occurs in fall; this harvest is substituted by grazing in the grazed swards. Grazing intensity is moderate, $0.2-0.4$ livestock units $\mathrm{ha}^{-1}$ or equivalent, and occurs late in the season. In the study area, most farmers maintain similar management practices (including rotation) for several years. Most sampled swards were sown as sainfoin monocultures, but some presented a mixture of this species with dactyl (Table 1). Most swards were sown in spring (Table 1). In total, 39 sainfoin swards were sampled in spring 2002 at peak biomass, right before the first, main harvest. Sampled swards varied in age from 1 to 6 years after sowing. Polls to farmers revealed that most swards were not older than 6 years. Sainfoin swards within the study region meeting the requirements above in the sampling year and for which environmental and management information was available were sampled. Details about sampled sward distribution per management are shown in Table 1.

At each sampled sward, environmental and management variables were recorded and/or investigated through interviews to the farmers: altitude, aspect, slope, macrotopography, sward age (year after sowing), previous crop, management treatment, mixture/monoculture, sainfoin variety, sowing season, sowing density, sward size (see Table 1 for details). A $2 \times 2-m$ plot was set in the middle of each selected sward and the number of plant species recorded to estimate species richness. Herbage was collected by harvesting $40.5 \times 0.5-\mathrm{m}$ sub-quadrats in the corners of each plot. Four separate subsamples were thus collected per sward; results from those subsamples were afterwards combined into a single compound replicate. Herbage from three of the four sub-quadrats was separated into species to determine vegetation composition, and sainfoin and unsown biomass and proportion. The fourth subsample was used for chemical analyses not presented here. All four subsamples were oven-dried to constant mass and the results combined to determine total aboveground biomass. A single measure was considered per sward by aggregating values from the subsamples.

\subsection{Data analysis}

We used constrained ordination by canonical correspondence analysis (CCA) to investigate the environmental factors controlling species composition. In particular, we were interested in the effect on vegetation composition of year after sowing, management treatment, monoculture/mixture with dactyl and the year $\times$ management interactions. Mixed swards were underrepresented in the dataset (Table 1) because they are less common in the study area, and therefore the monoculture/mixture $\times$ year interactions were not tested. The dependent variables were biomass per species and plot. Other environmental variables were included in the CCA analysis as covariates: altitude, aspect, slope, macrotopographical position, seeding density, previous crop, French/ local sainfoin variety, field size and sowing season. All categorical environmental variables were introduced as binary variables $(0 / 1)$ in the analyses. Stepwise forward selection of the multivariate model was performed iteratively using the partial Monte Carlo permutation test to asses the quality of each potential predictor or environmental variable. $F$ ratios and $p$ values were generated for each explanatory

Table 1 Main environmental and management characteristics of the sampled swards distributed according to the three main management treatments: sheep-grazed, cattle-grazed and only mown swards

\begin{tabular}{llll}
\hline & Sheep-grazed & Cattle-grazed & Only mown \\
\hline No. of samples & 24 & 9 & 6 \\
Altitude & $1,010-1,280$ & $685-1,200$ & $660-740$ \\
Field surface (ha) & $0.1-4$ & $0.3-1.6$ & $0.2-3$ \\
Sowing rate (kg seed ha ${ }^{-1}$ ) & $80-200$ & $80-100$ & $75-115$ \\
Potato vs. cereal as previous crop (\%) & 14 & 29 & 100 \\
French vs. local sainfoin variety (\%) & 50 & 51 & 33 \\
Sowing in spring vs. fall (\%) & $100 \%$ of swards & 66.6 & 100 \\
Mixture with dactyl vs. monoculture (\%) & 11 & 17 & 0 \\
Young swards (1-2 years, \%) & 38 & 44 & 17 \\
Perennial-to-annual ratio & 5.8 & 7.7 & 4.8 \\
Dominant plant species (excluding sainfoin) & Bromus diandrus & Plantago lanceolata & Crepis sancta \\
& Sanguisorba minor & Dactylis glomerata & Bromus tectorum \\
& Dactylis glomerata & Trifolium pratense & Sonchus asper \\
\hline
\end{tabular}


variable from randomization tests by 499 Monte Carlo permutations. The predictor variables selected with the forward method were mixture with dactyl, cattle grazing, sheep grazing, year after sowing, year $\times$ cattle grazing and year $\times$ sheep grazing.

The Bray-Curtis similarity index $(1-\mathrm{BC}$ dissimilarity index) was calculated to assess vegetation heterogeneity between and within treatments (sheep-grazed, cattle-grazed and only mown), as in Sebastià et al. (2008). The calculations were performed separately for young (1-2 years) and old (36 years) swards. To assess the variability of the composition similarity, confidence intervals $(\mathrm{CI})$ for the similarity indices were calculated intra-treatment by age category (young and old) and for some selected comparisons between management treatments. In addition, the comparison of the CI provides a crude estimate of the significance of the mean treatment differences.

We considered sward structural variables other than vegetation composition: plant species richness, total aboveground biomass, sainfoin biomass, and biomass and proportion of unsown species. Species richness was measured as the number of plant species per $2 \times 2-\mathrm{m}$ plot and used as an indicator of agro-diversity. To investigate the effect of the sward treatment factors on species richness and biomass variables, we used general linear modelling, including as explanatory factors of interest year after sowing, management, mixture with dactyl, and the other environmental and management variables listed above, as well as the management per year interactions. Plant species richness showed the most complex model in comparison with the biomass variables, and thus, those are presented separately. In addition, we developed a model relating sward aboveground biomass and species richness and other structural variables including unsown proportion, plus the environmental and management variables above and interactions, following the same techniques. Tukey's post hoc tests were applied for comparisons of means for significant factors. Estimated means and errors were calculated for some variables.

Table 2 Variables included in a canonical correspondence analysis related to changes in species composition in sainfoin swards

\begin{tabular}{lll}
\hline Factors & F & P-value \\
\hline Mixture with Dactylis glomerata & 1.58 & 0.0920 \\
Year after sowing & 1.99 & 0.0340 \\
Sheep grazing & 0.86 & 0.5780 \\
Cattle grazing & 1.43 & 0.1260 \\
Sheep $\times$ year & 2.10 & 0.0100 \\
Cattle $\times$ year & 2.13 & 0.0399
\end{tabular}

Results from multivariate canonical correspondence analysis for which $F$ and $p$ values were generated by 499 Monte Carlo permutations. The effect of only mowing is associated with the significance of sheep and cattle grazing

\section{Results and discussion}

\subsection{Management effects on plant species composition}

Different management treatments resulted in strong variations in plant composition, the effects increasing with sward age (Table 2 and Fig. 1). Indeed, over time, the similarity in vegetation composition decreased between and within treatments (Table 3). Although plots with different sward management were more similar to each other when young (1-2 years after establishment;

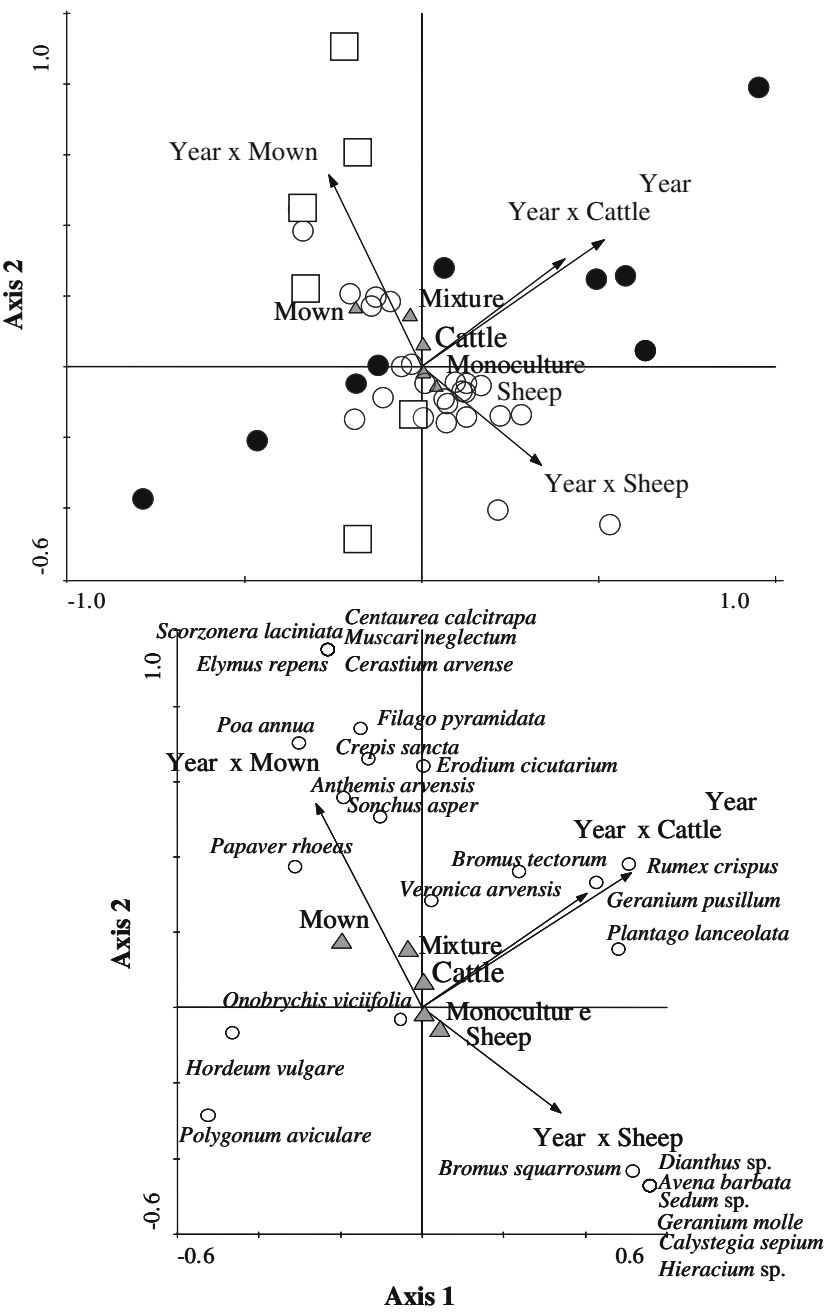

Fig. 1 Distribution of the sampled swards (above) and the species (below) in the space generated by the two first canonical correspondence analysis axes. Above: only mown (squares); sheep-grazed (open dots); cattle-grazed (filled dots). Below: species contributing more than $15 \%$ to fit are represented with small dots. The management treatments are represented in the same space. Arrows indicate the direction of change for quantitative variables (year after sowing and interactions). Triangles indicate the position of the categories for the qualitative variables (management treatment and sainfoin monoculture/mixture with dactyl). The distribution of samples and species shows strong shifts in vegetation composition with management that increase with time 
Table 3 Confidence intervals (95\%) for the Bray-Curtis vegetation similarity index calculated within and between treatments

\begin{tabular}{lccc}
\hline & Cattle-grazed & Sheep-grazed & Mown \\
\hline $\begin{array}{l}\text { Young swards } \\
\text { Cattle-grazed }\end{array}$ & $0.488-0.775$ & $0.656-0.727$ & $0.603-0.857$ \\
Sheep-grazed & & $0.713-0.771$ & $0.666-0.847$ \\
Mown & & & - \\
Old swards & & & \\
Cattle-grazed & $0.082-0.278$ & $0.208-0.425$ & $0.423-0.574$ \\
Sheep-grazed & & $0.408-0.489$ & $0.501-0.616$ \\
Mown & & & $0.525-0.641$ \\
\hline
\end{tabular}

Young swards are 1-2 years old; old swards are 3-6 years old. There were few young swards only mown, and therefore, confidence interval within this treatment was not calculated. The confidence intervals provide a rough estimate about differences between treatment means by comparing the overlap between treatments and about the variability within and between treatments depending on the values and range of the interval. The highest are the values in the confidence interval (and associated mean); the highest is the similarity between the treatments being compared

Table 3), the three sward managements produced different vegetation trajectories (Fig. 1 and Table 3). In particular, old cattle-grazed swards were more differentiated from the other treatments in terms of plant species composition than those between them according to the similarity analysis (Table 3). However, the lowest similarity was found within cattle-grazed plots, suggesting that cattle grazing generates high variability in species composition between different swards and therefore increases vegetation diversity at the landscape and regional levels (Table 3). This is probably linked to the fact that cattle are non-selective in their feeding habits (Rook et al. 2004) and must let express local differences in the plant species pool and in the responses of that pool to abiotic factors (Guretzky et al. 2007). The same pattern was found when comparing cattle-grazed and sheep-grazed perennial subalpine grass-

Table 4 Results from the modelling of plant species richness (measured as the number of species per plot) as a function of environmental and management variables

\begin{tabular}{llrr}
\hline Factors & $d f$ & $F$ & $p$ value \\
\hline Sward surface & 1 & 7.60 & 0.0098 \\
Mixture with dactyl & 1 & 3.75 & 0.0621 \\
Year after sowing & 1 & 22.74 & $<0.0001$ \\
Management & 2 & 3.73 & 0.0356 \\
Year $\times$ management & 2 & 5.38 & 0.0100 \\
\hline
\end{tabular}

Management tested against sheep grazing. The degrees of freedom $(d f), F$ ratios and $p$ values are indicated for each factor included in the final model. Only factors significant or improving the model, or main effects in significant interactions, are included in the final model presented lands in the Pyrenees (Sebastià et al. 2008) with an entirely different vegetation (Sebastià 2004). Our results suggest that in spite of the short-living nature of the system, there could be some long-lasting effects linked to the management of the sward (Pärtel 2002).

\subsection{Management effects on plant species diversity}

Plant species richness increased with time after sowing, but this effect was dependent on management (Table 4). The temporal differences were best shown in cattle-grazed and particularly in only mown plots (Fig. 2). In swards 6 years old, plots only mown had the highest mean number of plant species (estimated mean $34 \pm 3.4$ standard error (SE), species per plot), followed by cattle-grazed swards $(28 \pm 3.3 \mathrm{SE})$, and significantly higher $(p<0.0367)$ than sheep-grazed swards ( $24 \pm 1.8 \mathrm{SE})$. This confirms the positive effect of mowing on promoting species richness in meadows (Hansson and Fogelfors 2000; Fischer and Wipf 2002). However, old plots only mown had the highest within-treatment vegetation similarity (Table 3 ). Thus, the only mowing management enhances plant species diversity at the plot level; cattle grazing does so at the regional level. The combination of managements within the region enhances further overall plant diversity because of the differences in vegetation composition found among those.

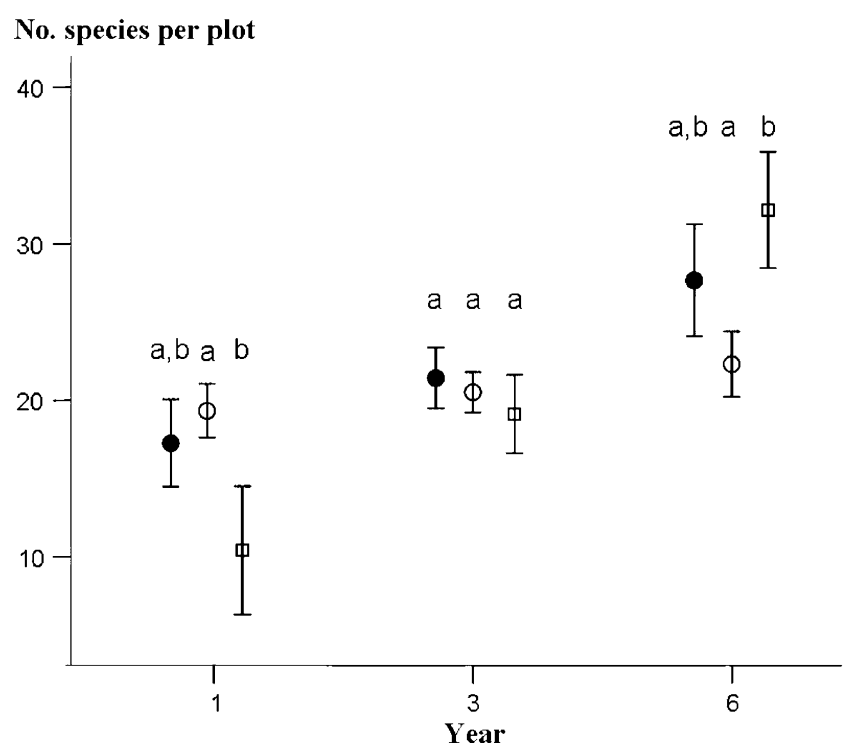

Fig. 2 Changes in mean \pm 1 SE number of species per plots (species richness) with sward age for the three sward managements: cattle grazing (filled dots); sheep grazing (open dots); only mown (open squares). All values estimated from model in Table 4 for 1,3 and 6 years after sowing. Different letters indicate significant differences between managements within a given year according to the mean separation Tukey test. Species richness varied with management and increased with time after sowing, particularly in only mown swards 
Table 5 Results from the modelling of four structural biomass parameters (sward biomass, sainfoin biomass, unsown species biomass and unsown species proportion)

\begin{tabular}{lllcr}
\hline & Sward biomass $\left(\mathrm{kg} \mathrm{m}^{-2}\right)$ & Sainfoin biomass $\left(\mathrm{kg} \mathrm{m}^{-2}\right)$ & Unsown biomass $\left(\mathrm{kg} \mathrm{m}^{-2}\right)$ & Unsown proportion $(\%)$ \\
\hline Mixture with dactyl & - & - & 0.0277 & 0.0589 \\
Year after sowing & 0.0132 & $<0.0001$ & 0.0004 & $<0.0001$ \\
$R^{2}$ & 0.15 & 0.35 & 0.35 & 0.49 \\
\hline
\end{tabular}

$P$ values are indicated for each factor included in the final model for each variable of interest. The $R^{2}$ of each model is shown. Only factors significant or improving the model are included in the final model presented

Another noteworthy result was the increase in plant species richness with increasing sward size (Table 4) even if the sampling area was kept constant $\left(4 \mathrm{~m}^{2}\right)$. This means that in big swards, there were more species per unit area than in small swards, which can have important consequences for species conservation.

\subsection{Management effects on aboveground biomass}

Aboveground biomass variables responded mostly to sward age, with most of the other factors being removed from the final models (Table 5). Both total aboveground biomass and sainfoin biomass decreased with years after sowing, independently of management, whilst unsown biomass and proportion increased over time (Table 5). The increase of unsown species with time after sowing was also independent of sward management (Table 5). There was a negative correlation between sainfoin biomass and biomass of unsown species $(r=-0.5313, p=0.0005)$. Over time, sainfoin decreases because of limited resprouting capacity (Chassagne and Chambon 1993). In the gaps resulting from sainfoin loss, because of decreased competition, the biodiversity stored in the soil seed bank can express itself and new species introduced with grazers can establish (Zobel et al. 2006; Sebastià et al. 2008).

Table 6 Results from the modelling of sward biomass in relation with species richness (measured as the number of species per subplot), proportion of unsown species, time after sowing, management and some first-order interactions

\begin{tabular}{lcrc}
\hline Factors & $d f$ & \multicolumn{1}{l}{$F$} & $p$ value \\
\hline Species richness & 1 & 1.27 & 0.2718 \\
Proportion of unsown species & 1 & 13.42 & 0.0012 \\
Seeding rate & 1 & 8.38 & 0.0080 \\
Year after sowing & 1 & 3.77 & 0.0641 \\
Management & 2 & 3.55 & 0.0447 \\
Species richness $\times$ management & 2 & 4.10 & 0.0293
\end{tabular}

Management tested against sheep grazing. The degrees of freedom, $(d f), F$ ratios and $p$ values are indicated for each factor included in the final model. Only factors significant or improving the model, or main effects in significant interactions, are included in the final model presented
Thein et al. (2008)) reported a positive effect of species richness on sainfoin biomass in mixtures based on both increased tillering and biomass per tiller. According to our model (Table 6), this effect can be lost depending on grazing. Indeed, we found a positive effect of plant species richness on aboveground biomass in sheep-grazed swards (estimated mean aboveground biomass $3,136 \mathrm{~kg} \mathrm{ha}^{-1}$ for species richness $=15 ; 4,171 \mathrm{~kg} \mathrm{ha}^{-1}$ for species richness $=$ 30 ) once the effect of unsown species was discounted for (Table 6). But the effect was negative in cattle-grazed swards $\left(4,400\right.$ and $\left.1,437 \mathrm{~kg} \mathrm{ha}^{-1}\right)$ and negligible in only mown swards $\left(2,174\right.$ and $\left.2,003 \mathrm{~kg} \mathrm{ha}^{-1}\right)$. Total aboveground biomass decreased when the proportion of unsown species increased (Fig. 3), which must be linked to the loss of the productive sainfoin species, but the relationship

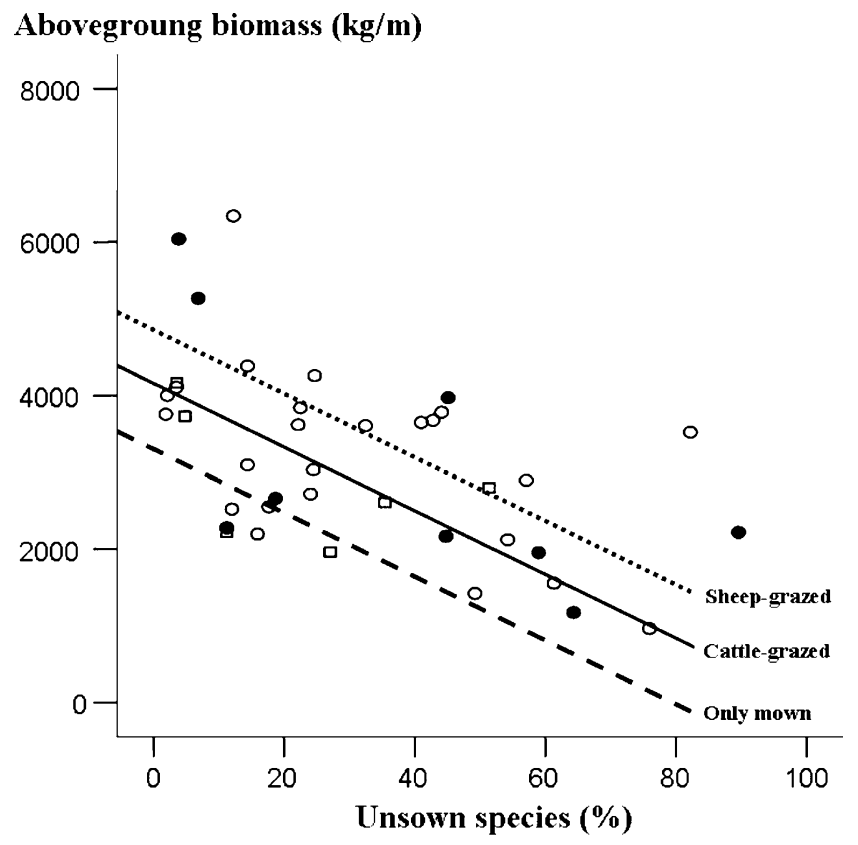

Fig. 3 Change in total aboveground biomass with unsown species proportion for the three sward managements. Dots represent actual data. Lines are drawn from predicted values obtained from the model in Table 6. Sheep grazing (open dots and dotted line); cattle grazing (filled dots and solid line); only mown (open squares and dashed line). Management tested against sheep grazing. Total aboveground biomass decreased with unsown species depending on management and diversity variables 
between them was mediated by other factors, including biodiversity and management (Table 6). According to the model, total biomass was also enhanced by increased seeding rate (Table 6). Contrary to expectations (Kirwan et al. 2007; Lithourgidis et al. 2007), we did not find an enhancement effect of mixing forage species on sward biomass. However, we found a marginal suppressive effect on unsown species (Table 5), as reported by those authors.

\section{Conclusion}

The present study shows strong effects of sward management on local biodiversity and herbage composition in legume-based forage swards. Furthermore, it shows that the combination of different sward managements within a region might promote overall biodiversity. Management effects often interacted with time, which was the main driver of vegetation change. The decrease of sainfoin over time, linked to sainfoin physiology and growth traits, let express the unsown flora by reduced competition. However, our results suggest that in spite of the short-living nature of the system, there could be some long-lasting effects linked to the traditional management of swards and in addition to the suppressive effect of the sown on the unsown plants at the beginning of sward existence.

Acknowledgements We thank the farmers in the study area for their help during the development of this work. A. Michelena and I. Delgado provided useful information about sainfoin in the Pyrenees. Useful comments by three anonymous reviewers, the field editor and the Editorin-Chief, E. Lichtfouse, contributed significantly to the improvement of the paper. The CARBOPAS (REN2002-04300-C02-01 and 02) and the CARBOAGROPAS (CGL2006-13555-C03-01/BOS) projects from the Spanish Science Foundation (FECYT), the Dept. Agricultura (DAR) and the Dept. Treball of the Catalan Government, the Fundació Territori i Paisatge (FTiP) and the I3A-5-147-E project of the EU INTERREG III-A program contributed with funding.

\section{References}

Bakker ES, Ritchie ME, Olff H, Milchunas DG, Knops JM (2006) Herbivore impact on grassland plant diversity depends on habitat productivity and herbivore size. Ecol Lett 9:780-788

Chassagne J, Chambon J (1993) Le sainfoin: une légumineuse pour les sols de Causse. Application à la région agricole de Gramat et de Lomogne, Fourrages 134:177-181

Cingolani AM, Noy-Meier I, Diaz S (2005) Grazing effects on rangeland diversity: a synthesis of contemporary models. Ecol Appl 15:757-773

Clergue B, Amiaud B, Pervanchon F, Lasserre-Joulin F, Plantureux S (2005) Biodiversity: function and assessment in agricultural areas. A review. Agron Sustain Dev 25:1-15. doi:10.1051/ agro:2004049

Common TG, Wright IA, Grant SA (1998) The effect of grazing by cattle on animal performance and floristic composition in Nardus-dominated swards. Grass Forage Sci 53:260-269 de Bello F, Thuiller W, Lepš J, Choler P, Clément J-C, Macek P, Sebastià M-T, Lavorel S (2009) Partitioning of functional diversity reveals the scale and extent of trait convergence and divergence. J Veg Sci 20:475-486

del Pozo M, Osoro K, Celaya R (1998) Effects of complementary grazing by goats on sward composition and on sheep performance managed during lactation in perennial ryegrass and white clover pastures. Small Ruminant Research 29:173-184

Delgado I, Andrés C, Sin E, Ochoa MJ (2005) Current state of sainfoin (Onobrychis viciifolia Scop.) in Spain. Agricultura Revista Agropecuaria 74:146-149

Fischer M, Wipf S (2002) Effect of low-intensity grazing on the species-rich vegetation of traditionally mown subalpine meadows. Biol Conserv 104:1-11

Grant SA, Torvell L, Sim EM, Small JL, Armstrong RH (1996) Controlled grazing studies on Nardus grassland. I. Effects of between tussock sward height and species of grazer on Nardus utilisation and floristic composition in two fields in Scotland. J Appl Ecol 33:1053-1064

Guretzky JA, Moore KJ, Burras CL, Brummer EC (2007) Plant species richness in relation to pasture position, management, and scale. Agric Ecosyst Environ 122:387-391

Hansson M, Fogelfors H (2000) Management of a semi-natural grassland: results from a 15-year-old experiment in southern Sweden. J Veg Sci 11:31-38

Kirwan L, Lüscher A, Sebastià MT, Finn JA, Collins RP, Porqueddu C, Helgadottir A, Baadshaug OH, Brophy C, Coran C, Dalmannsdóttir S, Delgado I, Elgersma A, Fothergill M, Frankow-Lindberg BE, Golinski P, Grieu P, Gustavsson AM, Höglind M, Huguenin-Elie O, Iliadis C, Jørgensen M, Kadziuliene Z, Karyotis T, Lunnan T, Malengier M, Maltoni S, Meyer V, Nyfeler D, Nykanen-Kurki P, Parente J, Smit HJ, Thumm U, Connolly J (2007) Evenness drives consistent diversity effects in an agronomic system across 28 European sites. J Ecol 95:530-539

Lithourgidis AS, Dhima KV, Vasilakoglou IB, Dordas CA, Yiakoulaki MD (2007) Sustainable production of barley and wheat by intercropping common vetch. Agron Sustain Dev 27:95-99

Marriott CA, Carrère P (1998) Structure and dynamics of grazed vegetation. Ann Zootech 47:359-369

Matejkova I, van Diggelen R, Prach K (2003) An attempt to restore a central European species-rich mountain grassland through grazing. Appl Veg Sci 6:161-168

Mellado M, Rodríguez A, Villarreal J, Rodríguez R, Salinas J, López R (2004) Gender and tooth wear effects on diets of grazing goats. Small Ruminant Research 57:105-114

Nelson E, Mendoza G, Regetz J, Polasky S, Tallis H, Cameron DR, Chan MKA, Daily GC, Goldstein J, Kareiva PM, Lonsdorf E, Naidoo R, Ricketts TH, Shaw MR (2009) Modeling multiple ecosystem services, biodiversity conservation, commodity production, and tradeoffs at landscape scales. Frontiers in Ecology and the Environment 7:4-11

Pakeman RJ (2004) Consistency of plant species and trait responses to grazing along a productivity gradient: a meta-analysis. J Ecol 92:893-905

Pärtel M (2002) Local plant diversity patterns and evolutionary history at the regional scale. Ecology 83:2361-2366

Pavlů V, Hejcman M, Pavlů L, Gaisler J, Nežerková P (2006) Effect of continuous grazing on forage quality, quantity and animal performance. Agric Ecosyst Environ 113:349-355

Pickett STA (1989) Space-for-time substitutions as an alternative to long-term studies. In: Likens GE (ed) Long-term studies in ecology. Springer, New York, pp 110-135

Quétier F, Téebault A, Lavorel S (2007) Plant traits in a state and transition framework as markers of ecosystem response to landuse change. Ecol Monogr 77:33-52 
Rook AJ, Dumont B, Isselstein J, Osoro K, Wallis-DeVries MF, Parente G, Mills J (2004) Matching type of livestock to desired biodiversity outcomes in pastures: a review. Biol Conserv 119:137-150

Sanderson MA, Skinner RH, Barker DJ, Edwards GR, Tracy BF, Wedin DA (2004) Plant species diversity and management of temperate forage and grazing land ecosystems. Crop Sci 44:1132-1144

Sebastià MT (2004) Role of topography and soils in grassland structuring at the landscape and community scales. Basic Appl Ecol 5:331-346
Sebastià MT, de Bello F, Puig L, Taull M (2008) Grazing as a factor structuring grasslands in the Pyrenees. Appl Veg Sci 11:215-222

Semelová V, Hejcmanb M, Pavlůc V, Vaceka S, Podrázskýa V (2008)

The grass garden in the Giant Mts. (Czech Republic): residual effect of long-term fertilization after 62 years. Agric Ecosyst Environ 123:337-342

Thein S, Roscher C, Schulze E-D (2008) Effects of trait plasticity on aboveground biomass production depend on species identity in experimental grasslands. Basic Appl Ecol 9:475-484

Zobel M, Öpik M, Moora M, Pärtel M (2006) Biodiversity and ecosystem functioning: it is time for dispersal experiments. J Veg Sci 17:543-547 